\title{
Pearls \& Oy-sters: Nonmotor Seizures as Presenting Feature of Hodgkin Lymphoma CNS Involvement
}

\author{
Dioselina Panamá Tristán-Samaniego, MD, Miguel García-Grimshaw, MD, Rogelio Domínguez-Moreno, MD, \\ Fernanda Sofía García-Miranda, MD, Griselda Teresa Romero-Sánchez, MD, MSc, \\ Orlando Emmanuel Falcón-Antonio, MD, Oswaldo Alan Chávez-Martínez, MD, \\ Gladys Patricia Agreda-Vásquez, MD, and Carlos Cantú-Brito, MD, PhD
}

Neurology ${ }^{\circledR}$ 2021;96:e2239-e2242. doi:10.1212/WNL.0000000000011238

\section{Pearls}

- CNS involvement in Hodgkin lymphoma is extremely rare, and usually presents with focal weakness, nonspecific sensitive symptoms, headache, altered mental status, and seizures.

\section{Oy-sters}

- CNS involvement usually presents during advanced stages, most commonly within the first 2 years after the initial diagnosis.

- CSF findings are nonspecific with low positivity rates on flow cytometry, which makes essential the need for tissue sampling.

A 43-year-old woman hospitalized for acute bacterial cholangitis treated with piperacillin/ tazobactam and meropenem developed on day 10 of in-hospital stay an episode of abrupt headache followed by paresthesia of the right arm and a speech impairment lasting more than 15 minutes. Her medical history was relevant for a high-risk (international prognostic score of 4 points) stage IVB classical (mixed cellularity) Hodgkin lymphoma (HL) with lymphatic, gastrointestinal, hepatic, and bone marrow involvement diagnosed 4 months before admission. She was receiving treatment with AVDB (adriamycin, bleomycin, vinblastine, and dacarbazine) chemotherapy and had received the fourth cycle 1 month before admission.

Upon examination, vital signs were within the normal range. The patient was alert but unable to communicate correctly; speech was fluent with impaired comprehension. She was able to repeat simple phrases with semantic paraphasias and echolalia, findings consistent with sensitive transcortical aphasia; the rest of the examination was unremarkable. Blood workup was relevant for mild anemia of $10.2 \mathrm{~g} / \mathrm{dL}$ (reference 14.5-17.7) with a normal white blood cell and platelet count. Serum electrolytes, coagulation, liver, and renal function tests were normal. To approach a neurovascular cause, we performed an urgent brain MRI, which showed an ill-defined, contrast-enhancing lesion on the left parietal lobe with mixed pachymeningeal and leptomeningeal involvement and prominent vasogenic perilesional edema (figure, A-E).

Right after the MRI was finished, the aphasia resolved spontaneously. On interrogation, the patient referred to having experienced a similar event, which lasted 10-15 minutes, 2 months before. She also complained of a progressive mild to moderate daily headache, exacerbated by daily life activities, without nausea or vomiting, for the past 3 months. While being prepared for an EEG 1 hour after the first episode, she developed another similar event. Under suspicion of focal onset, nonmotor seizures, we performed a benzodiazepine test with $10 \mathrm{mg}$ of IV diazepam,

\author{
Correspondence \\ Dr. García-Grimshaw \\ miguelgrimshaw@gmail.com
}

From the Departments of Neurology and Psychiatry (D.P.T.-S., M.G.-G., R.D.-M., O.A.C.-M., C.C.-B.), Hematology (F.S.G.-M., G.P.A.-V.), Neuroradiology (G.T.R.-S.), and Pathology (O.E.F.-A.), Instituto Nacional de Ciencias Médicas y Nutrición Salvador Zubirán, Mexico City, Mexico.

Go to Neurology.org/N for full disclosures. Funding information and disclosures deemed relevant by the authors, if any, are provided at the end of the article. 


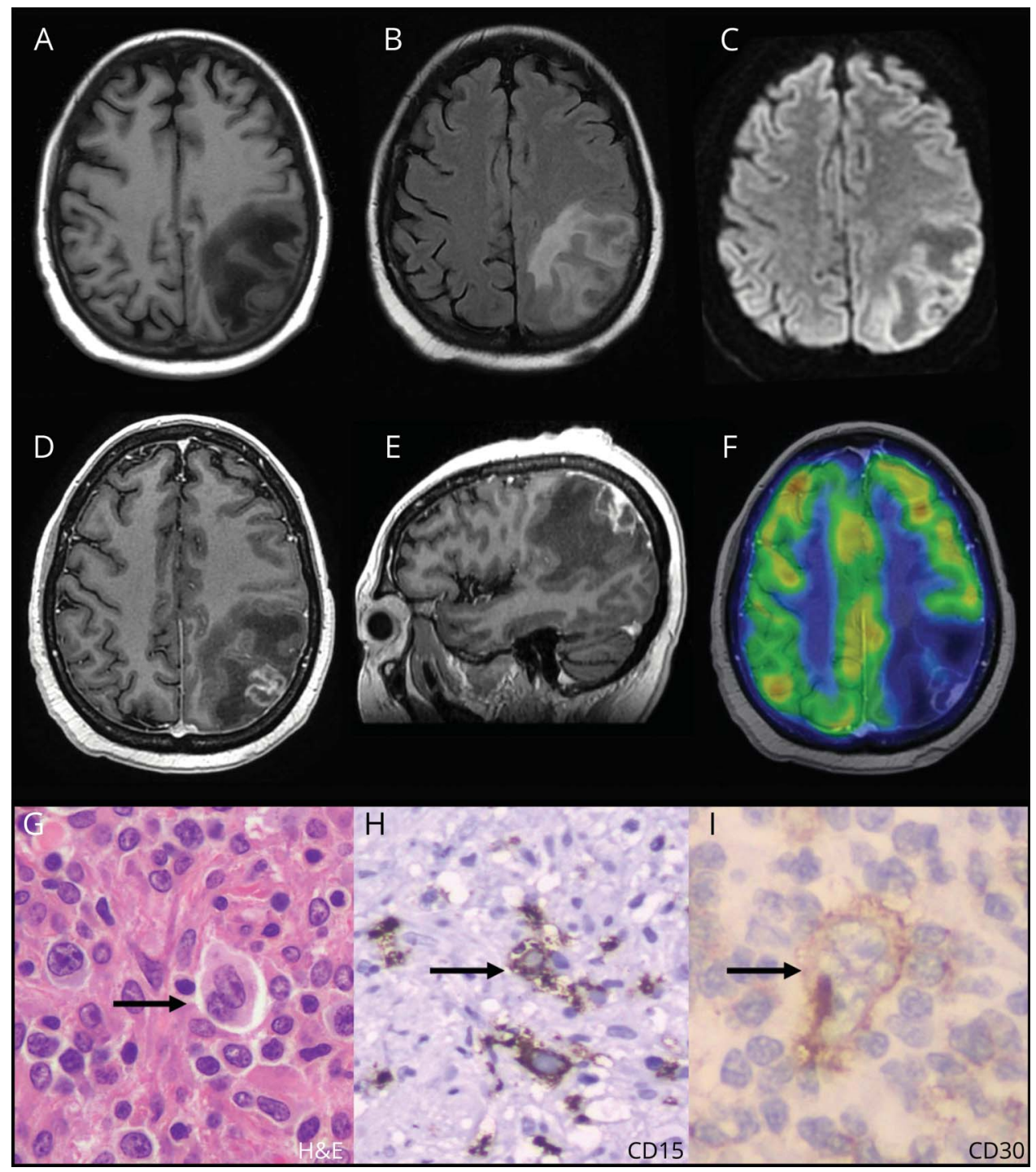

(A) Axial T1-weighted image (T1WI) shows an ill-defined lesion in the left parietal lobe. (B) Axial fluid-attenuated inversion recovery image shows perilesional edema. (C) Axial diffusion-weighted image demonstrates the lesion with peripheral restriction. (D) Axial and (E) sagittal contrast-enhanced T1WI show a heterogenous enhancing lesion with a central necrotic component associated with mixed pachymeningeal and leptomeningeal enhancement. (F) Axial fused ${ }^{18} \mathrm{FDG}$-PET and contrast-enhanced T1WI shows regional parietal lobe hypometabolism. (G) Hematoxylin \& eosin stain at $200 \times$ shows a large binucleated cell with conspicuous nucleoli and prominent eosinophilic cytoplasm (arrow), the pathognomonic Hodgkin lymphoma Reed-Sternberg cell, with positive immunohistochemistry staining (arrows) for (H) CD15 and (I) CD30.

which resolved the symptoms. An EEG performed after the administration of benzodiazepines revealed slow background rhythm within theta range on the left temporal and parietal lobes without epileptiform activity. Then we started treatment with IV levetiracetam.

A whole-body ${ }^{18}$ F-fluorodeoxyglucose $\left({ }^{18}\right.$ F-FDG $)$ PET/CT showed resolution of the initial hepatic and gastrointestinal involvement with partial response of the lymphadenopathies (Deauville score of 2), and brain PET/MRI fused images showed a decreased ${ }^{18}$ F-FDG uptake of the CNS lesion. CSF analysis showed only mildly elevated proteins of $68 \mathrm{mg} / \mathrm{dL}$ (reference 15-45) with normal white cells (3 cells/ $\mu \mathrm{L}$ [reference $0-10])$, glucose $(68 \mathrm{mg} / \mathrm{dL}$ [reference $50-80])$, and $\mathrm{CSF} /$ serum glucose ratio. Gram and acid-fast bacilli stains were negative as well as PCR for herpes simplex viruses 1 and 2, varicella-zoster virus, Epstein-Barr virus, Toxoplasma gondii, and Mycobacterium tuberculosis. CSF was also negative for malignancy, by morphology and flow cytometry.

Because of the inconclusive neuroimaging findings, under suspicion of $\mathrm{HL}$ progression to the CNS, we performed a complete surgical removal of the lesion. Histopathologic analysis showed lymphocytic infiltration and Reed-Sternberg cells, with positive immunohistochemistry staining for CD30, CD15 (figure, G-I), latent membrane protein-1 (LMP-1), and paired box 5 (PAX5) antibody, consistent with a diagnosis of HL. After confirming progression to the CNS, we started local treatment with whole-brain radiation plus systemic therapy with monthly brentuximab vedotin $(1.8 \mathrm{mg} /$ $\mathrm{kg}$ ). The patient was discharged 25 days after admission on levetiracetam $500 \mathrm{mg}$ twice a day. On follow-up 4 months after discharge, the patient remains asymptomatic without any further seizures. 


\section{Discussion}

$\mathrm{HL}$ is a hematologic neoplasm that arises from B-cells, accounting for $10 \%$ of all newly diagnosed lymphoma cases. In the early stages, it is usually limited to the lymph nodes, although it can also involve extranodal sites. On histopathologic analysis, the neoplastic cells appear as multinucleated giant cells or large mononuclear cells, better known as the pathognomonic Reed-Sternberg cells. ${ }^{1}$ CNS involvement of $\mathrm{HL}$ is rare, with a frequency of $0.02 \%-0.07 \%{ }^{2,3}$ usually presenting in advanced stages, but can occur at the time of diagnosis or during a relapse. ${ }^{3,4}$ Furthermore, it can also have other neurologic manifestations, such as paraneoplastic syndromes (e.g., cerebellar degeneration) and treatment-related complications. ${ }^{1,5,6}$ Because of the rarity of CNS involvement, the knowledge of these patients' clinical characteristics derives from a few case reports and small case series.

A case series of 16 patients with intracranial involvement of HL reported that $56 \%$ of patients were male, with a mean age at presentation of 45 years. Median time from initial diagnosis of $\mathrm{HL}$ to CNS involvement was 11.7 (6.9-18.9) months, and 9 out of $13(69 \%)$ patients were in complete response at the time of diagnosis. ${ }^{4}$ Another case series that included patients from an international multicenter study of 30,781 patients with HL found only $21(0.07 \%)$ histologically confirmed cases. In this study, $52 \%$ were male, with a median age at onset of 40 years (range 18-84). The median time from the initial diagnosis of HL to CNS involvement was 1.9 years (range $0.4-6.6$ ), with an overall response rate of $65 \%$ and median overall survival of 29 months during a 3.6-year follow-up. ${ }^{3}$ From these findings, we can partially conclude that CNS involvement in $\mathrm{HL}$ is slightly more frequent in male patients during the fifth decade of life and that it usually develops within the first 2 years after the initial diagnosis of HL.

The clinical presentation reported within these series was as follows: pyramidal weakness $(18 \%-35 \%)$, nonspecific sensitive manifestations including pain $(20 \%-31 \%)$, headache $(18 \%-25 \%)$, altered mental status $(15 \%-18 \%)$, seizures $(5 \%-18 \%)$, aphasia $(5 \%)$, and ataxia $(5 \%))^{3,4}$ Our patient's clinical presentation included headache, paresthesia, and focal seizures. Pathophysiologic mechanisms of intracranial involvement in HL remains incompletely understood; the proposed hypotheses include hematogenous dissemination of the neoplastic cells to the meninges or surrounding bony structures with subsequent brain involvement or direct parenchymal dissemination. ${ }^{7}$ Those hypotheses could explain the neuroimaging findings, with isolated parenchyma involvement in $58 \%-83 \%$ of cases, leptomeningeal involvement in $15 \%-31 \%$, or both in $5 \%-26 \%$.,

The reported locations within the parenchyma are highly variable, and there are no specific neuroimaging findings for distinguishing $\mathrm{HL}$ infiltration from other etiologies, such as a brain abscess. Also, CSF findings are nonspecific, the most common finding being an elevation of proteins in a wide range, varying from 0 to $245 \mathrm{mg} / \mathrm{dL}$. CSF flow cytometry is positive only in $22 \%-45 \%$ of cases, ${ }^{3,4}$ making the diagnosis even harder without a brain biopsy. Nevertheless, when possible, CSF analysis with flow cytometry constitutes a feasible way to approach these patients.

There is a wide variation of treatment modalities that can be used, including guided radiotherapy alone, whole-brain radiation, multiagent systemic chemotherapy, and total or subtotal surgical resection. ${ }^{3,4,7}$ The most constant reported treatment is a combination of whole-brain radiation with systemic chemotherapy. ${ }^{3,4}$ Recently, in a phase 3 trial, a combination of brentuximab vedotin (an anti-CD30 antibody-drug conjugate) plus standard chemotherapy was shown to improve the risk of progression, death, or noncomplete response in patients with advanced stages of $\mathrm{HL}$ during a 2-year follow-up. ${ }^{8}$ Regarding its use in patients with CNS involvement, there is only 1 case report in which the patient received brentuximab vedotin plus standard chemotherapy and consolidation with autologous stem cell transplantation followed by brentuximab vedotin maintenance. In this report, the authors showed a durable partial response of 18 months in highly refractory HL with CNS involvement. However, the patient died 6 months after the last dose of brentuximab vedotin. ${ }^{9}$

Because of the rarity of CNS involvement, screening for any new neurologic symptoms in patients with a known history of $\mathrm{HL}$ is mandatory. Any brain space-occupying lesion in these patients should be thoroughly investigated to rule out secondary causes such as a brain abscess, making essential the need for tissue sampling as it can prompt the diagnosis of a progressive or relapsing disease, which may improve the prognosis of these patients.

\section{Study Funding}

No targeted funding reported.

\section{Disclosure}

The authors report no disclosures relevant to the manuscript. Go to Neurology.org/N for full disclosures.

Appendix Authors

\begin{tabular}{|c|c|c|}
\hline Name & Location & Contributions \\
\hline $\begin{array}{l}\text { Dioselina } \\
\text { Panamá } \\
\text { Tristán- } \\
\text { Samaniego, } \\
\text { MD }\end{array}$ & $\begin{array}{l}\text { Instituto Nacional de } \\
\text { Ciencias Médicas y } \\
\text { Nutrición Salvador } \\
\text { Zubirán, Mexico City, } \\
\text { Mexico }\end{array}$ & $\begin{array}{l}\text { Designed and } \\
\text { conceptualized study, } \\
\text { collected and analyzed } \\
\text { the data, drafted the } \\
\text { manuscript for } \\
\text { intellectual content }\end{array}$ \\
\hline $\begin{array}{l}\text { Miguel García- } \\
\text { Grimshaw, MD }\end{array}$ & $\begin{array}{l}\text { Instituto Nacional de } \\
\text { Ciencias Médicas y } \\
\text { Nutrición Salvador } \\
\text { Zubirán, Mexico City, } \\
\text { Mexico }\end{array}$ & $\begin{array}{l}\text { Designed and } \\
\text { conceptualized study, } \\
\text { collected and analyzed } \\
\text { the data, drafted the } \\
\text { manuscript for } \\
\text { intellectual content }\end{array}$ \\
\hline
\end{tabular}


Appendix (continued)

\begin{tabular}{|c|c|c|}
\hline Name & Location & Contributions \\
\hline $\begin{array}{l}\text { Rogelio } \\
\text { Domínguez- } \\
\text { Moreno, MD }\end{array}$ & $\begin{array}{l}\text { Instituto Nacional de } \\
\text { Ciencias Médicas y } \\
\text { Nutrición Salvador } \\
\text { Zubirán, Mexico City, } \\
\text { Mexico }\end{array}$ & $\begin{array}{l}\text { Designed and } \\
\text { conceptualized study, } \\
\text { collected and analyzed } \\
\text { the data, drafted the } \\
\text { manuscript for } \\
\text { intellectual content }\end{array}$ \\
\hline $\begin{array}{l}\text { Fernanda Sofía } \\
\text { García- } \\
\text { Miranda, MD }\end{array}$ & $\begin{array}{l}\text { Instituto Nacional de } \\
\text { Ciencias Médicas y } \\
\text { Nutrición Salvador } \\
\text { Zubirán, Mexico City, } \\
\text { Mexico }\end{array}$ & $\begin{array}{l}\text { Designed and } \\
\text { conceptualized study, } \\
\text { collected and analyzed } \\
\text { the data, drafted the } \\
\text { manuscript for } \\
\text { intellectual content }\end{array}$ \\
\hline $\begin{array}{l}\text { Griselda } \\
\text { Teresa } \\
\text { Romero- } \\
\text { Sánchez, MD, } \\
\text { MSc }\end{array}$ & $\begin{array}{l}\text { Instituto Nacional de } \\
\text { Ciencias Médicas y } \\
\text { Nutrición Salvador } \\
\text { Zubirán, Mexico City, } \\
\text { Mexico }\end{array}$ & $\begin{array}{l}\text { Collected and analyzed } \\
\text { the data, drafted the } \\
\text { manuscript for } \\
\text { intellectual content }\end{array}$ \\
\hline $\begin{array}{l}\text { Orlando } \\
\text { Emmanuel } \\
\text { Falcón- } \\
\text { Antonio, MD }\end{array}$ & $\begin{array}{l}\text { Instituto Nacional de } \\
\text { Ciencias Médicas y } \\
\text { Nutrición Salvador } \\
\text { Zubirán, Mexico City, } \\
\text { Mexico }\end{array}$ & $\begin{array}{l}\text { Collected and analyzed } \\
\text { the data, drafted the } \\
\text { manuscript for } \\
\text { intellectual content }\end{array}$ \\
\hline $\begin{array}{l}\text { Oswaldo Alan } \\
\text { Chávez- } \\
\text { Martínez, MD }\end{array}$ & $\begin{array}{l}\text { Instituto Nacional de } \\
\text { Ciencias Médicas y } \\
\text { Nutrición Salvador } \\
\text { Zubirán, Mexico City, } \\
\text { Mexico }\end{array}$ & $\begin{array}{l}\text { Collected and analyzed } \\
\text { the data, drafting, and } \\
\text { revision for intellectual } \\
\text { content }\end{array}$ \\
\hline $\begin{array}{l}\text { Gladys Patricia } \\
\text { Agreda- } \\
\text { Vásquez, MD }\end{array}$ & $\begin{array}{l}\text { Instituto Nacional de } \\
\text { Ciencias Médicas y } \\
\text { Nutrición Salvador } \\
\text { Zubirán, Mexico City, } \\
\text { Mexico }\end{array}$ & $\begin{array}{l}\text { Designed and } \\
\text { conceptualized study, } \\
\text { analyzed the data, } \\
\text { drafting, and revision for } \\
\text { intellectual content }\end{array}$ \\
\hline $\begin{array}{l}\text { Carlos Cantú- } \\
\text { Brito, MD, PhD }\end{array}$ & $\begin{array}{l}\text { Instituto Nacional de } \\
\text { Ciencias Médicas y } \\
\text { Nutrición Salvador } \\
\text { Zubirán, Mexico City, } \\
\text { Mexico }\end{array}$ & $\begin{array}{l}\text { Designed and } \\
\text { conceptualized study, } \\
\text { analyzed the data, } \\
\text { drafting, and revision for } \\
\text { intellectual content }\end{array}$ \\
\hline
\end{tabular}

\section{References}

1. Shanbhag S, Ambinder RF. Hodgkin lymphoma: a review and update on recent progress: current progress in Hodgkin lymphoma. CA Cancer J Clin 2018;68: 116-132.

2. Re D, Fuchs M, Schober T, Engert A, Diehl V. CNS involvement in Hodgkin's lymphoma. J Clin Oncol 2007;25:3182.

3. Cheah CY, Bröckelmann PJ, Chihara D, et al. Clinical characteristics and outcomes of patients with Hodgkin lymphoma with central nervous system involvement: an international multicenter collaboration. Am J Hematol 2016;91:894-899.

4. Gerstner ER, Abrey LE, Schiff D, et al. CNS Hodgkin lymphoma. Blood 2008;112: 1658-1661.

5. Hammack J, Kotanides H, Rosenblum MK, Posner JB. Paraneoplastic cerebellar degeneration: II: clinical and immunologic findings in 21 patients with Hodgkin's disease. Neurology 1992;42:1938.

6. Graus F, Ariño H, Dalmau J. Paraneoplastic neurological syndromes in Hodgkin and non-Hodgkin lymphomas. Blood 2014;123:3230-3238.

7. van Blydenstein SA, Patel M, Philip V, et al. Classical Hodgkin lymphoma involving the central nervous system (brain): an unusual presentation. Clin Case Rep 2014;2: $88-92$.

8. Connors JM, Jurczak W, Straus DJ, et al. Brentuximab vedotin with chemotherapy for stage III or IV Hodgkin's lymphoma. N Engl J Med 2018;378:331-344.

9. Mociková H, Malikova H, Holesta M, Elturki A, Campr V, Kozak T. Durable response to brentuximab vedotin-based chemotherapy in refractory Hodgkin lymphoma with central nervous system (CNS) involvement. Am J Case Rep 2020;21:e921657. 


\section{Neurology}

\section{Pearls \& Oy-sters: Nonmotor Seizures as Presenting Feature of Hodgkin Lymphoma CNS Involvement \\ Dioselina Panamá Tristán-Samaniego, Miguel García-Grimshaw, Rogelio \\ Domínguez-Moreno, et al.}

Neurology 2021;96;e2239-e2242 Published Online before print November 20, 2020

DOI 10.1212/WNL.0000000000011238

This information is current as of November 20, 2020

\section{Updated Information \& Services}

References

Subspecialty Collections

Permissions \& Licensing

Reprints including high resolution figures, can be found at: http://n.neurology.org/content/96/17/e2239.full

This article cites 9 articles, 4 of which you can access for free at: http://n.neurology.org/content/96/17/e2239.full\#ref-list-1

This article, along with others on similar topics, appears in the following collection(s):

All Clinical Neurology

http://n.neurology.org/cgi/collection/all_clinical_neurology All Epilepsy/Seizures

http://n.neurology.org/cgi/collection/all_epilepsy_seizures All Oncology

http://n.neurology.org/cgi/collection/all_oncology

Hematologic

http://n.neurology.org/cgi/collection/hematologic

Information about reproducing this article in parts (figures,tables) or in its entirety can be found online at:

http://www.neurology.org/about/about_the_journal\#permissions

Information about ordering reprints can be found online:

http://n.neurology.org/subscribers/advertise

Neurology ${ }^{\circledR}$ is the official journal of the American Academy of Neurology. Published continuously since 1951, it is now a weekly with 48 issues per year. Copyright (C 2020 American Academy of Neurology. All rights reserved. Print ISSN: 0028-3878. Online ISSN: 1526-632X.

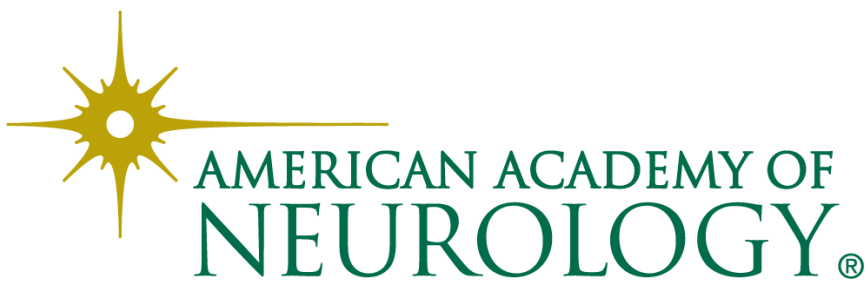

